\title{
A ESTÉTICA DA EXCLUSÃO: \\ IMIGRANTES CHINESES EM CULTURAS VISUAIS \\ BRASILEIRAS NA VIRADA DO SÉCULO XX ${ }^{1}$
}

Ana Paulina Lee ${ }^{2}$

$\mathrm{A}$

$\mathrm{s}$ teorias raciais, o racismo científico e a ideologia da eugenia produziram novas estruturas do racismo e subjetividades racializadas que influenciaram os debates sobre a construção da nação brasileira e a transformação econômica representada pela transição do trabalho escravo para o trabalho assalariado. ${ }^{3}$ Intelectuais, políticos e fazendeiros consideravam a imigração vinda da Europa, da Ásia e do Oriente Médio um meio de modernizar a economia. Nesse contexto, a abolição se entrelaçava ao branqueamento racial e à ideologia eugenista, e o "ideal civilizador do trabalho livre" se consubstanciava nas discussões sobre branquitude e identidade nacional. ${ }^{4} \mathrm{Na}$ sociedade em geral, as preocupações com as necessidades da economia ao longo da transição do trabalho forçado para o trabalho livre se misturavam às questões da demografia racial do país. ${ }^{5}$ Definir a branquitude também significava

1 Agradeço os comentários dos dois pareceristas anônimos da Afro-Ásia.

2 Professora assistente do Departamento de Culturas Latino-Americanas e Ibéricas, Universidade Colúmbia. ana.lee@columbia.edu.

3 Lilia Moritz Schwarcz, O espetáculo das raças: cientistas, instituições e questão racial no Brasil, 1870-1930, São Paulo: Companhia das Letras, 1993; Silvio Luiz de Almeida, Racismo estrutural, São Paulo: Pólen, 2019; Celia Maria Marinho de Azevedo, Dois estudos sobre imigração e racismo, São Paulo: Annablume, 2015.

4 Alfredo Bosi, Dialética da colonização, São Paulo: Companhia das Letras, 1992.

5 Emília Viotti da Costa, "Permanência do sistema escravista", in Da senzala à colônia (São Paulo: Difusão Europeia do Livro, 1966), pp. 169-201; Gilberto Freyre, "O Oriente e o 
definir como a nação modificaria seu perfil populacional, de mais negro para mais branco, e assimilaria imigrantes que não eram nem brancos nem negros; ${ }^{6}$ embora a branquitude estivesse em alta conta, tratava-se de uma construção maleável que não se referia simplesmente à cor da pele. $^{7}$ As ideologias raciais foram fundamentais na reconfiguração da divisão internacional do trabalho, no que diz respeito à constituição de uma nova classe de trabalhadores migrantes dispensáveis e substituíveis no processo de produção capitalista.

Este artigo enfoca as culturas de exclusão e racialização de chineses, propondo uma mudança de foco dos discursos raciais sobre negros, brancos, mestiços e indígenas, que tendem a dominar as discussões acadêmicas sobre raça no Brasil. Essa mudança de foco é uma tentativa de pensar de maneira comparada as histórias da diferença racial nas Américas e examinar as maneiras pelas quais a produção estética funcionou em paralelo às teorias raciais para estruturar novas relações sociais de produção capitalista. Essas novas relações sociais assumiram características de estruturas jurídicas de exclusão política e social nos projetos de construção de nações emergentes. Meu foco nos debates sobre a imigração chinesa examina a história social da produção intelectual entre o Brasil e a China, e os projetos teóricos de nação nas trocas intelectuais entre esses dois impérios periféricos, em um momento de radical reconfiguração geopolítica, econômica e sócio-histórica.

Políticos e elites agrícolas brasileiras achavam que os trabalhadores chineses forneceriam uma solução temporária para a crise de mão de obra. ${ }^{8}$ As culturas visuais ajudaram a produzir e circular um conjunto

Ocidente", in Sobrados e mucambos: decadência do patriarcado rural e desenvolvimento do urbano (Rio de Janeiro: Record, 1996), pp. 41-110.

6 Thomas Skidmore, Black into White: Race and Nationality in Brazilian Thought, Durham: Duke University Press, 1993, p. 24; Jeffrey Lesser, Immigration, Ethnicity, and National Identity in Brazil, 1808 to the Present, Cambridge: Cambridge University Press, 2013, p. 23; Karoline Carula, "A raça em foco", in Darwinismo, raça e gênero: projetos modernizadores da nação em conferências e cursos públicos: Rio de Janeiro, 1870-1889 (Campinas: Editora da Unicamp, 2016), pp. 155-208.

7 Lesser, Immigration, Ethnicity, p. 10.

8 Maria José Elias, "Os debates sobre o trabalho dos chins e o problema da mão de obra no Brasil durante o século XIX" (Dissertação de Mestrado, Universidade de São Paulo, 1972); Alexander Chung Yuan Yang, "O Comércio dos 'Coolie' 1810-1920” (Dissertação de Mestrado, Universidade de São Paulo, 1974); José Roberto Teixeira Leite, "Imigração chinesa para o 
de códigos simbólicos que enquadravam os imigrantes chineses como uma "raça amarela", dentro de contornos ideológicos que identificavam certas raças com certos tipos de trabalho. A mão de obra chinesa foi representada enquanto um contingente de trabalhadores baratos que ameaçava o status da mão de obra livre. ${ }^{9} \mathrm{Na}$ mídia impressa circulavam caricaturas e comentários jocosos sobre os chineses, que relacionavam preocupações econômicas e políticas com o perigo da miscigenação da população brasileira com a chamada "raça amarela". ${ }^{10}$

As representações raciais da chinesidade não se relacionam apenas à definição da identidade nacional brasileira, mas mostram também o surgimento de uma semiótica global de raça. A produção cultural visual e sua circulação eram um modo dominante de transferir ideologias raciais construídas durante o período da escravidão para o chamado "trabalho amarelo". Esses regimes estéticos funcionavam como uma tecnologia de criação de raça e contribuíam para consolidar diferentes formas de nacionalismo racializado em todo o mundo. Aqui, coloco o trabalho de Micol Seigel sobre a geopolítica de categorias nacionais racializadas em diálogo com as contribuições de Rebecca Karl para discutir o nacionalismo não apenas no interior dos próprios países, mas no contexto global das assimetrias e desigualdades expressas em termos raciais. ${ }^{11} \mathrm{~A}$ disseminação mundial de culturas visuais antichinesas fez circular os mesmos símbolos em diversos países durante a segunda metade do século XIX.

Brasil", China em Estudo, ano 2, n. 2 (1995), pp. 25-40; Rogério Dezem, Matizes do "amarelo": a gênese dos discursos sobre orientais no Brasil (1878-1908), São Paulo: Humanitas, 2005; Shu Chang-Sheng, "Imigrantes e imigração chinesa no Rio de Janeiro (1910-1990)", Leituras da História, n. 17 (2009), pp. 44-53.

9 Hoang Gia Phan, “'A Race So Different': Chinese Exclusion, the Slaughterhouse Cases and Plessy v. Ferguson", Labor History, v. 45, n. 2 (2004), p. 154.

10 Jeffrey Lesser, "Neither Slave nor Free, Neither Black nor White: the Chinese in Early Nineteenth Century Brazil", Estudios Interdisciplinarios de América Latina e el Caribe, v. 5, n. 2 (1995), pp. 23-34; Jeffrey Lesser, Negotiating National Identity: Immigrants, Minorities, and the Struggle for Ethnicity in Brazil, Durham: Duke University Press, 1999; Dezem, Matizes do "amarelo", 2005; Silvio Cezar de Souza Lima, "Determinismo biológico e imigração chinesa em Nicolau Moreira (1870-1890)" (Dissertação de Mestrado, Casa de Oswaldo Cruz, Fiocruz, 2005); Lúcia Maria Bastos Pereira Neves, Lucia Maria Paschoal Guimarães e Tânia Bessone da Cruz Ferreira, "O Império do Cruzeiro do Sul e a Corte Celeste de Tien-Tsin: apontamentos sobre as relações sino-brasileiras no século XIX”, Navigator, v. 6, n. 2 (2010), p. 66-75.

11 Micol Seigel, Uneven Encounters: Making Race and Nation in Brazil and the United States, Durham: Duke University Press, 2009, p. 27; Rebecca Karl, Staging the World: Chinese Nationalism at the Turn of the Twentieth Century, Durham: Duke University Press, 2002, p. 24. 
A repetição dos símbolos visuais da racialização de chineses difundidos em diferentes países não era mera coincidência, mas constituía uma estética da exclusão chinesa. No Brasil, esse discurso de exclusão tomou forma predominantemente na cultura visual e circulou amplamente na mídia impressa. Na imprensa brasileira, a diversidade étnica entre os imigrantes chineses foi apagada em favor da visão homogeneizadora que os percebia como pertencentes a uma raça única. A estética da exclusão nas teorias brasileiras sobre nação e nos discursos raciais do trabalho subjugado abarcou todos os imigrantes chineses, independentemente de suas diferenças étnicas e condições de trabalho. Essa estética da exclusão criou um discurso coerente sobre os chineses que os considerava impróprios para o Brasil moderno, que caminhava em direção à branquitude e ao capitalismo industrial.

Por sua vez, intelectuais e diplomatas Qing estavam interessados em criar suas próprias versões da China no Brasil, via yizhi (uma palavra que significa tanto imigração quanto colonização). Os intelectuais Qing temiam que o fim da China estivesse próximo e viam no Brasil uma possibilidade de construir uma nova China, através da expansão econômica e política, por meio da contratação de trabalhadores chineses no exterior. As visitas desses intelectuais provocaram muito debate entre abolicionistas e defensores da escravidão no Brasil, sendo apropriadas pelas narrativas dos abolicionistas que lutavam pela emancipação e pela república. As visões brasileiras e Qing sobre a figura do trabalhador migrante chinês revelam uma consciência global emergente de imaginações nacionais racializadas que se expandiram para além dos territórios de cada estado-nação. Examinar as missivas diplomáticas do final da dinastia Qing sobre o papel que os chineses poderiam desempenhar na abertura de rotas de imigração e comércio entre a China e o Brasil - tendo em vista o contexto das preocupações dos abolicionistas brasileiros com a emancipação e a independência nacional - mostra como as representações raciais da chinesidade continham várias camadas de significados geopolíticos. Esse período coincidiu com os anos de transição que levaram à liberalização econômica, que também devem ser entendidos no contexto da transição global do trabalho escravo para novos modos de trabalho precário. 
No Brasil, enquanto a imigração chinesa foi sempre indesejada, a visão sobre a imigração japonesa oscilava entre períodos em que esta era vista como benéfica, até para se contrapor à imigração chinesa, e períodos em que também era vista como indesejável..$^{12}$ As ideias em constante mutação em relação a chineses e japoneses estavam ligadas às ambições de expansão imperialista desses dois países, que tomaram forma nos esquemas de imigração de mão de obra e no estabelecimento de laços simbólicos e estruturais entre os colonos e a pátria. Os defensores da escravidão criaram narrativas sobre a emancipação que transformaram a imigração chinesa, ou o chamado "trabalho amarelo", em uma metáfora para a precária condição de liberdade. Construções da chinesidade, simultânea e contraditoriamente, produziram visões dos chineses ora como colonos, ora como escravos. A figura do coolie personificava o trabalhador migrante racializado que cumpriria as promessas da expansão imperialista via imigração-colonização e forneceria uma mão de obra precarizada e facilmente substituível para a construção de uma nova China no Brasil. Na produção cultural brasileira e nos escritos diplomáticos Qing, as ilustrações dos trabalhadores chineses oscilam entre a esperança e a ameaça à nação: eles poderiam fornecer uma solução para a crise de mão de obra, mas sua condição precária os tornava inadequados para o liberalismo branco a que o Brasil aspirava.

Essa visão dos colonos chineses como inadequados prejudicou as metas estatais chinesas de expansão econômica por meio da emigração. No Brasil, visões emergentes sobre os chineses e japoneses como uma única raça figuravam no projeto de branqueamento da população durante o período da emancipação gradual, e persistiram durante o período republicano. As visões do final do século XIX a respeito de trabalho, raça e liberdade eram influenciadas por ideias sociais e eugênicas darwinistas sobre miscigenação, e os debates sobre a miscigenação e a produtividade do trabalho entrelaçavam-se a discussões sobre a identidade nacional brasileira e o republicanismo. Alberto Torres (1865-1917), jurista e presidente do Rio de Janeiro de 1896 a 1900, expressou a opinião de que os mulatos ocupavam uma posição social intermediária, hierarquicamente

12 Priscila Nucci, Os intelectuais diante do racismo antinipônico no Brasil: textos e silêncios, São Paulo: Annablume, 2010. 
posicionada acima da população negra, mas ao mesmo tempo nunca totalmente aceita pela classe monopolista branca. ${ }^{13}$ As representações raciais da figura da mulata simbolizavam sua posição intermediária no espectro racial, no âmbito do qual o indivíduo tinha tanto mais valor social e político quanto mais próximo estivesse do polo branco, e mais distante do polo negro.

Narrativas sobre miscigenação com chineses apareciam nas construções correntes sobre raça. Alguns acreditavam que a miscigenação poderia ser uma forma de resgatar os chineses de sua condição de indesejáveis, de modo que pudessem ser progressivamente assimilados até o ponto de sua erradicação. ${ }^{14}$ Outras perspectivas consideravam que a miscigenação com chineses seria uma ameaça à virilidade da nação, uma vez que o "amarelecimento" não apenas eliminaria a negritude, mas também erradicaria a branquitude. ${ }^{15} \mathrm{O}$ discurso sobre a sexualidade dos chineses ganhou uma função simbólica na medida em que os governantes ponderavam sobre a maior ou menor contribuição econômica que aqueles poderiam aportar ao Estado brasileiro. Essas representações ambíguas levavam a uma visão da imigração chinesa como uma faca de dois gumes: poderiam levar o Brasil a um estado de progresso baseado no trabalho livre civilizado ou, ao contrário, a uma economia colonial atrasada baseada no trabalho escravo.

As ideias sociais darwinistas sobre a miscigenação generativa ou degenerativa com os chineses estavam de fato circulando por todo o mundo, inclusive nos Estados Unidos, onde os trabalhadores chineses eram representados por meio de um espectro de estereótipos desumanizantes. Representações recorrentes dos chineses retratavam olhos exageradamente puxados, camisas com botões de nó, sapatos pontudos e, mais proeminentemente, a trança da dinastia Qing, que simbolizava a lealdade ao imperador. Em uma imagem de 1877 intitulada "Ilustração da teoria de Darwin: a criação do chinês e do porco", que apareceu na publicação The Wasp, os chineses eram caricaturados como uma etapa

13 Alberto Torres, O problema nacional brasileiro: introdução a um programa de organização nacional, Rio de Janeiro: Imprensa Nacional, 1914, p. 62.

14 Lesser, Negotiating National Identity, p. 15.

15 Dezem, Matizes do "amarelo". 
evolutiva entre o rato e o porco. A ilustração mostrava características físicas tais como uma longa trança, semelhante a um rabo de rato e a um porco híbrido. ${ }^{16}$ Essas representações não eram meramente produtos da imaginação; nos Estados Unidos, a produção da cultura visual a respeito de trabalhadores chineses preparou o terreno para um ambiente cultural de restrições imigratórias sem precedentes, baseadas na raça e na classe. A chamada "questão chinesa" difundiu em escala mundial a ideia de que os chineses eram incapazes de se integrar às nações para onde migravam. A “questão chinesa global”, como observa Mae Ngai, agrupou todos os trabalhadores chineses, independentemente de seu status, em uma categoria homogênea, uma "raça coolie" que representava uma ameaça ao trabalho livre branco, abrindo caminho para políticas de exclusão antichinesas nos Estados Unidos e ao redor do mundo. ${ }^{17}$

Os debates sobre a "questão global chinesa" nos permitem examinar regimes raciais concomitantes que acompanharam a liberalização econômica global e se formaram em contextos diferentes, ainda que relacionados. A Lei de Exclusão Chinesa de 1882, assinada pelo presidente dos Estados Unidos, Chester Arthur, foi a primeira lei federal a proibir a imigração com base em raça e classe. A lei restringiu as fronteiras dos EUA da competição econômica com a mão de obra chinesa, que poderia concorrer com a mão de obra branca, usando a retórica da raça para garantir a ideia de uma homogeneidade racial da nação. ${ }^{18}$ A Lei de Exclusão Chinesa causou um efeito cascata em outros países, demonstrando as dimensões globais do nacionalismo racial: as restrições de imigração dos Estados Unidos e as tentativas de assegurar suas fronteiras raciais e nacionais produziram uma mudança nos padrões de imigração dos países da América do Sul, que passaram a vetar as mesmas etnias excluídas pela democracia liberal branca dos Estados Unidos. O sentimento antichinês homogeneizava os trabalhadores chineses enquanto uma

16 "Darwin's Theory Illustration: the Creation of Chinaman and Pig" apud Philip P. Choy, Lorraine Dong e Marlon K. Hom (eds.), The Coming Man: 19th Century American Perceptions of the Chinese (Seattle: University of Washington Press, 1994), p. 111.

17 Mae Ngai, "Chinese Gold Miners and the 'Chinese Question' in Nineteenth-Century California and Victoria", Journal of American History, v. 101, n. 4 (2015), pp. 1082-1105.

18 Elliott Young, Alien Nation: Chinese Migration in the Americas from the Coolie Era through World War II, Chapel Hill: University of North Carolina Press, 2014, p. 98. 
"raça coolie" e, dessa forma, transmitia a percepção de que se tratava de corpos codificados racialmente como não civilizados, sub-humanos e sujos - como marcadores do "estrangeiro exótico" que, por isso mesmo, poderia ter o acesso à cidadania negado. ${ }^{19}$ Eram corpos antidemocráticos, não livres e, portanto, não "americanos": sujeitos políticos impróprios e excluídos do direito à cidadania estadunidense. ${ }^{20}$

Nos Estados Unidos, o nacionalismo racializado e a competição econômica entre trabalhadores brancos e chineses alimentaram sentimentos antichineses que foram difundidos em escala global e aportaram no Brasil no contexto completamente novo do projeto de branqueamento da Primeira República. ${ }^{21}$ Nos anos que se seguiram à proibição da imigração chinesa nos Estados Unidos, as autoridades da dinastia Qing enxergaram em lugares da América do Sul, como o Brasil, uma opção favorável para a expansão política e econômica chinesa por meio da emigração de colonos. Durante a segunda metade do século XIX, as autoridades Qing revogaram todas as proibições à emigração. Além de assinar o Tratado de Pequim de 1860 e o Tratado de Burlingame de 1868, que suspendiam as proibições e legalizavam a emigração chinesa, a atitude governamental da dinastia Qing sobre os chineses que viviam no exterior também mudou: eles deixavam de ser traidores da pátria que mereciam a morte como castigo e passavam a ser vítimas de "estrangeiros gananciosos" e "contrabandistas chineses". 22

Entre os chineses, circulava o sentimento de que a restrição à sua entrada nos Estados Unidos era "particularmente injusta e desprezível”. ${ }^{23}$ Diplomatas Qing contestaram a percepção negativa dos estadunidenses

19 Nayan Shah, Stranger Intimacy: Contesting Race, Sexuality, and the Law in the North American West, Berkeley: University of California Press, 2011, p. 38.

20 Krystyn Moon, Yellowface: Creating the Chinese in American Popular Music and Performance, 1850s-1920s, New Brunswick: Rutgers University Press, 2005, p. 115.

21 Entre 1890 e 1892, foi aprovado um decreto que proibia africanos e asiáticos de entrar no Brasil. "Decreto $\mathrm{n}^{\circ}$ 528, de 28 de junho de 1890", Coleção de Leis do Brasil, v. 1, fasc. 6 (1890), p. 1424, <http://www2.camara.leg.br/legin/fed/decret/1824-1899/decreto-528-28-junho-1890-506935-publicacaooriginal-1-pe.html>, acessado em 24/1/2016. Embora os chineses não tenham sido mencionados explicitamente, as discussões na época deixaram claro que eles eram o foco da proibição.

22 Guanhua Wang, In Search of Justice: the 1905-1906 Chinese Anti-American Boycott, Cambridge: Harvard University Press, 2001, p. 40.

23 Wang, In Search of Justice, p. 40. 
com relação aos chineses que levara à promulgação da Lei de Exclusão Chinesa. Xue Fucheng alegou que a população dos Estados Unidos em geral acreditava que o povo chinês era feio e tinha a fama de comer animais não comestíveis nos Estados Unidos. Da mesma forma, Cui Guoyin, ministro chinês dos Estados Unidos, Espanha e Peru, observou que as ações ilegais de chineses no exterior, incluindo o contrabando de ópio e guerras entre facções tong nas Chinatowns das principais cidades estadunidenses, haviam fornecido motivos para a proibição. Essas críticas obscureciam um problema maior, nomeadamente a falta de representação política dos chineses residentes no quadro do sistema democrático dos Estados Unidos. ${ }^{24}$

\section{$* * *$}

As imagens antijaponesas do final do século XIX e do início do século XX que circulavam na imprensa brasileira assemelhavam-se ao discurso antichinês predominante, que descrevia esse povo como racialmente inferior, anti-higiênico e retrógrado. ${ }^{25}$ Essas culturas visuais negativas em torno do "amarelamento" constituíam um sistema racial semiótico que transmitia ideias sobre o "perigo amarelo". O discurso do "risco amarelo" que circulava pelo mundo expressava a ameaça de domínio asiático sobre o Ocidente e homogeneizava ideias sobre japoneses e chineses. A produção cultural visual foi fundamental para difundir essas ideias, que atravessaram fronteiras linguísticas e nacionais - independentemente das diferenças linguísticas, os símbolos visuais do sentimento contra a mão de obra asiática se transmitiam rapidamente através das fronteiras nacionais.

Códigos visuais como caricaturas com olhos puxados se tornaram uma metonímia para o imperialismo japonês, bem como para a mão de obra chinesa. As culturas visuais que representavam o perigo amarelo produziram sujeitos políticos asiáticos unidimensionais, que representavam uma ameaça ao poder militar ocidental e à sua dominação econômica. A estética do perigo amarelo fornece um exemplo de regime

24 Wang, In Search of Justice, p. 45.

25 Lesser, "Neither Slave nor Free"; Lesser, Negotiating National Identity; Dezem, Matizes do "amarelo". 
racial que implantou representações raciais com objetivos geopolíticos e econômicos. Durante os séculos XIX e XX, a cultura popular e os meios de comunicação descreviam os asiáticos enquanto uma raça amarela e ameaçadora - representações raciais que eram poderosas armas políticas, já que essa desumanização permite um "distanciamento psicológico" que facilita a limpeza étnica, o genocídio e o assassinato durante um confronto militar. ${ }^{26}$

O discurso do perigo amarelo surgiu em 1895, quando o Kaiser Wilhelm II da Alemanha cunhou a expressão em referência à vitória do Japão sobre a China na Primeira Guerra Sino-Japonesa (1894-1895), também conhecida como "guerra amarela". No entanto, como observa Tchen, a tropologia do perigo amarelo fazia parte de um mal-estar social maior, sendo, portanto, incorreto atribuir a criação de todo um discurso a uma única pessoa. ${ }^{27}$ No Brasil, atitudes antichinesas preexistentes influenciaram as percepções gerais sobre os japoneses, mas o governo japonês trabalhou de forma concertada para mudar essas visões negativas por meio da diplomacia e da oferta de apoio econômico e político aos japoneses emigrados. Em 1894, o diplomata japonês Sho Nemoto chegou ao Brasil e passou a divulgar a ideia de que os súditos japoneses podiam ser a solução para a escassez brasileira de mão de obra e o caminho para o progresso nacional; ao contrário dos europeus, os colonos japoneses seriam trabalhadores, calados e ansiosos para se tornarem brasileiros. ${ }^{28}$

O ano de 1908 marcou o início oficial da imigração japonesa no Brasil. O Kasato-Maru, primeiro navio a fazer viagem entre os dois países, transportou 781 passageiros. Ao longo da viagem de 51 dias, os imigrantes foram preparados para a vida no Brasil por meio da exibição de filmes para informá-los sobre a chegada ao país e da oferta de aulas de

26 John W. Dower, War Without Mercy: Race and Power in the Pacific War, New York: W.W. Norton, 1986, p. 9.

27 John Kuo Wei Tchen, “'The Yellow Claw': the Optical Unconsciousness in Anglo-American Political Cultures", in Christine Bold (org.), The Oxford History of Popular Print Culture (Oxford: Oxford University Press, 2012), v. 6, p. 489.

28 Jeffrey Lesser, "In Search of the Hyphen: Nikkei and the Struggle over National Brazilian Identity", in Lane Hirabayashi, Akemi Kikumura-Yano e James Hirabayashi (orgs.), New Worlds, New Lives: Globalization and People of Japanese Descent in the Americas and from Latin America in Japan (Stanford: Stanford University Press, 2002), p. 5. 
português. ${ }^{29}$ Esse foi o início oficial e bilateralmente sancionado da imigração japonesa no Brasil. ${ }^{30}$ Quando os japoneses chegaram, os brasileiros ficaram impressionados ao vê-los vestindo roupas europeias, que haviam comprado em fábricas do Japão. ${ }^{31}$ Esses esforços apontam uma campanha mais ampla entre as elites japonesas para retratar o Japão como um país "branco". ${ }^{32}$ De todas essas formas e mais, a imigração japonesa foi diferente da experiência dos imigrantes da China, que enfrentaram condições e tratamento igualmente severos, mas careciam de proteção do governo. Os colonos japoneses tinham o poderoso governo Meiji apoiando-os, e o Império estava bastante presente em suas vidas diárias do outro lado do mundo. Em 1908, um diplomata japonês mediou uma disputa entre trabalhadores japoneses e um fazendeiro brasileiro e, em apenas um ano, empresas público-privadas japonesas criaram colônias habitadas só por japoneses no estado de São Paulo. As colônias japonesas tinham sistemas escolares que seguiam o ano letivo japonês, e o governo lhes enviava livros e outros materiais. ${ }^{33} \mathrm{O}$ Estado japonês vigiava e controlava essas colônias, pois sua produtividade era uma grande fonte de receita para o crescente império militar, e o governo desempenhou um papel fundamental na transformação das imagens negativas dos japoneses a fim de facilitar a realização dos objetivos do Estado japonês no Brasil. ${ }^{34}$

29 Lesser, Immigration, Ethnicity, cap. 6.

30 Armando Akio, "Kasato Maru, o navio da esperança", <http://www.imigracaojaponesa.com. br/index.php/nossa-\%20historia/curiosidades/kasato-maru-o-navio-da-esperanca/>, acessado em 12/03/2020.

31 Akio, "Kasato Maru".

32 Lesser, Immigration, Ethnicity, cap. 6.

33 Lesser, Immigration, Ethnicity, cap. 6.

34 Nem todos os migrantes japoneses agiram em nome dos objetivos estatais japoneses. Muitos viajaram para o exterior em busca de aventura e de adquirir riquezas pessoais. No final da década de 1880, grupos de trabalhadores japoneses, principalmente jovens solteiros e sem dinheiro, com sonhos de riqueza e aventura, foram para o exterior como dekasegi (trabalhadores temporários no exterior) ou shosei (estudantes que trabalham). Eles foram para as plantações de cana-de-açúcar do Havaí e da costa pacífica da América do Norte - Yasuo Sakata, "Beginning of Overseas Dekasegi", in Japanese Overseas Migration Museum [exhibition catalogue] (Yokohama: Japanese International Cooperation Agency, 2004), p. 16; Alan Takeo Moriyama, Imingaisha: Japanese Emigration Companies and Hawaii, 1894-1908, Honolulu: University of Hawaii Press, 1985. 


\section{China no Brasil}

O governo Qing combateu o enfraquecimento de sua situação política e econômica ordenando uma série de missões de coleta de informações no Japão, nos Estados Unidos, na Europa e nas Américas. As autoridades governamentais esperavam obter informações sobre a condição dos trabalhadores chineses no exterior e avaliar as possibilidades de modernização na agricultura, indústria e comércio. Em 1876, o governo Qing começou oficialmente a enviar missões regulares ao exterior, ordenando que os delegados mandassem periodicamente relatórios que abordassem tópicos como canalização, desenvolvimento militar, indústria, literatura e cultura, e relações geopolíticas. ${ }^{35}$ As missões foram divididas em grupos youli (investigativos) orientais e ocidentais, cujas descobertas deveriam trazer uma perspectiva global para a visão etnocêntrica insular do regime Qing. Elas abriram caminho para o envio de novas levas de chineses ao exterior, com o intuito de mobilizar vários projetos nacionais do final da era Qing, incluindo uma emergente consciência nacional chinesa na esfera política e o empreendedorismo econômico no exterior. ${ }^{36}$

$\mathrm{Fu}$ Yunlong, secretário sênior do Ministério da Guerra, liderou o grupo Dongyang (oceano oriental), responsável por investigar seis países: Japão, Estados Unidos, Canadá, Peru, Brasil e Cuba. ${ }^{37}$ Uma das principais preocupações de Fu Yunlong era aproveitar as políticas mais brandas de imigração, em face dos efeitos globais das restrições estadunidenses à mão de obra chinesa. ${ }^{38} \mathrm{~A}$ América Latina significou um novo começo para a expansão da China por meio da migração de seus trabalhadores, de cuja atividade igualmente se poderia beneficiar. Totalizando 68 volumes e mapas ilustrados, os registros diários de Fu Yunlong fornecem uma riqueza de materiais que supera as contribuições de seus

35 Dong Shouyi e Wang Yanjing, "Chinese Investigative Missions Overseas, 1866- 1907", in Douglas Reynolds (ed.), China: 1895-1912 State-Sponsored Reforms and China's Late-Qing Revolution: Selected Essays from Zhongguo Jindai Shi: Modern Chinese History, 1840- 1919 (New York: Routledge, 1995), p. 18.

36 Karl, Staging the World, p. 80.

37 Shouyi e Yanjing, "Chinese Investigative", p. 21.

38 Fu Yunlong, "Carta para Li Hongzhang, 31 out. 1892”, in Fu Xuncheng (comp.), Fu Yunlong Riji [O diário de Fu Yunlong], (Hangzhou: Zhejiang guji chu ban she, 2005), pp. 387-388. 
pares (Figura 1). ${ }^{39}$ Até a virada do século XX, o Brasil era em grande parte uma terra incógnita para os Qing, exceto por algumas noções prévias que o representavam como um país selvagem. ${ }^{40} \mathrm{Fu}$ Yunlong desmistificou essas ideias atribuindo-as ao Zhi fang waiji (Crônica de terras estrangeiras), um texto escrito em 1623, no final da era Ming, no qual os indígenas brasileiros eram retratados com a retórica negativa dos tropos europeus da conquista, como bárbaros não civilizados e sem instrução: nus, caçadores, canibais, inocentes e analfabetos. ${ }^{41}$ Ao passo que rejeitava essas imagens negativas como falsidades, $\mathrm{Fu}$ Yunlong enfatizou aspetos favoráveis da paisagem e dos nativos que criavam uma imagem positiva do Brasil: o gosto dos brasileiros pelo lazer, pela comida, pelo tempo passado em família, e sua grande afinidade por nadar nos rios. Ele foi claro ao enfatizar que eles não trabalhavam; antes, os negros realizavam todo o trabalho. ${ }^{42}$

39 Wang, In Search of Justice, p. 41; Eric Vanden Bussche, "Travel Literature and the Transformation of Qing China's Perceptions of Brazil during the Late Nineteenth Century", 34th Annual Meeting of the Latin American Studies Association (New York, 2016).

40 Bussche, "Travel Literature".

41 Fu Yunlong, "Baxi feng su [Alfândega no Brasil]", in Baxi tujing [Mapa de viagem do Brasil] ([China]: [s. n.], 1901 [Guangxu 27]), v. 4.

42 Yunlong, "Baxi feng su". 
Figura 1 - Mapa de viagens de Fu Yunlong no Brasil, 190143

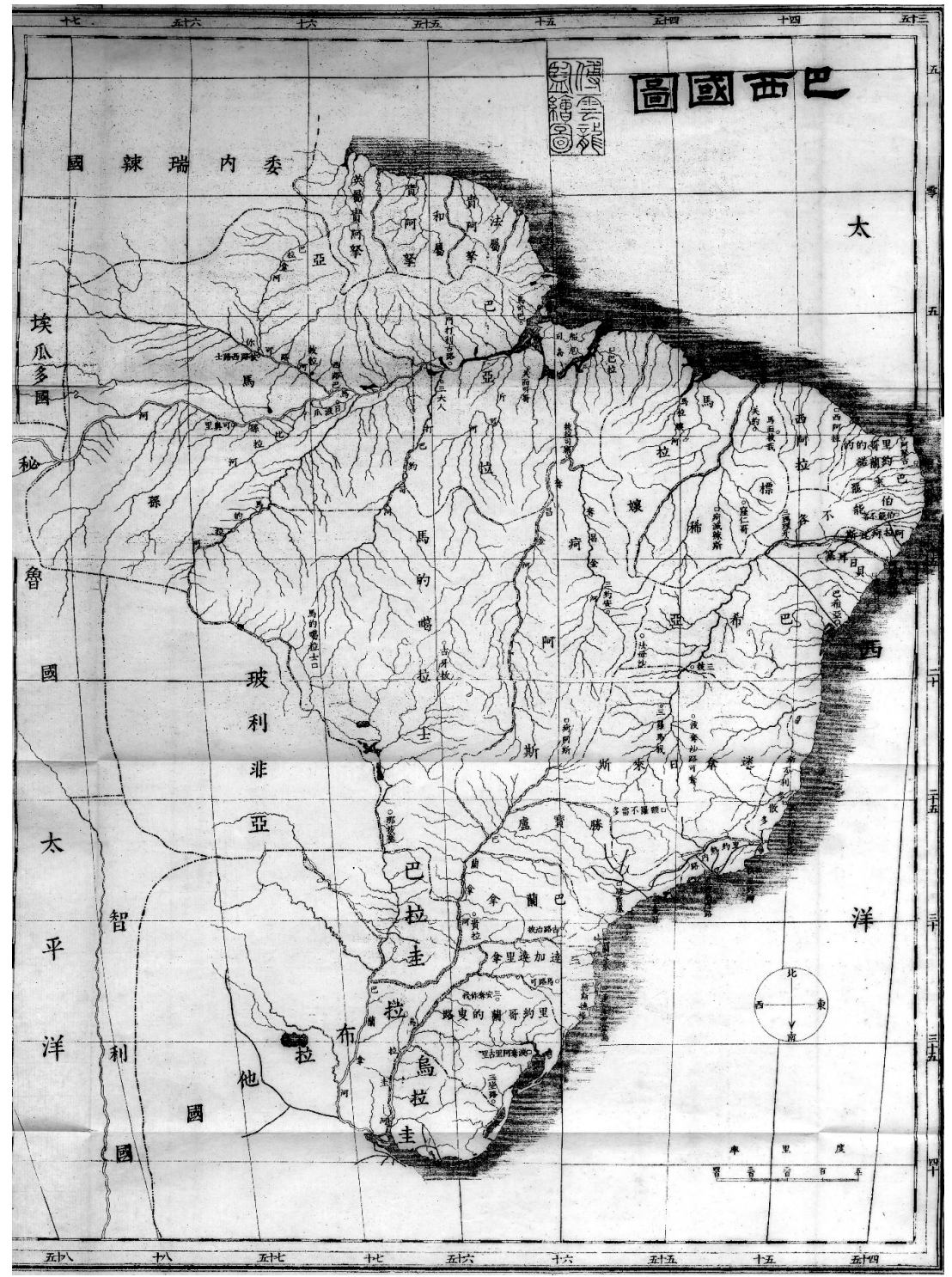

43 Fu Yunlong, Youli baxi guo tu jing, [China]: [s. n.]: 1901 [Guangxu 27], 10 v., livro com folhas duplas no caso de mapa dobrado $(26 \mathrm{~cm})$. 
Como o Brasil era uma nação jovem e nos estágios iniciais da imigração, ele estimou que este país poderia acomodar entre 200 e 300 mil trabalhadores chineses, uma escala sem paralelo em qualquer outro lugar. ${ }^{44}$ Contestando relatos bem conhecidos da exploração de chineses no exterior, em lugares como Cuba e Estados Unidos, ele retratou favoravelmente as condições de trabalho no Brasil, pintando um retrato unidimensional e romantizado da condição das pessoas escravizadas, afirmando que os brasileiros raramente tratavam os escravos cruelmente e que havia mobilidade social: eles recebiam abrigo e alimentação, podiam plantar e vender sua colheita, e com essas receitas muitas pessoas compravam a alforria. Uma vez obtida a liberdade, tornavam-se cidadãos.

Essas visões vendiam uma ideia do Brasil como uma terra vasta, pronta para receber o afluxo da população camponesa da China. Ao romantizar a escravidão e representar os povos indígenas como uma classe ociosa, $\mathrm{Fu}$ Yunlong criou uma representação do Brasil e de seus habitantes que ressaltava suas possibilidades agrícolas, suas indústrias extrativas e seu potencial para abrigar novos trabalhadores. Suas representações escritas e ilustradas da paisagem e do povo brasileiro promoveram a ideia de que este era um lugar hospitaleiro para o povo chinês. Enfatizando as terras disponíveis e as condições de trabalho favoráveis, ele dividiu a população do Brasil em minzu (etnias): 1) chineses; 2) portugueses; 3) britânicos, franceses, italianos e suíços; 4) ex-escravos negros emancipados que se tornaram cidadãos; 5) indígenas; e 6) grupos diversos sem linhagem clara. ${ }^{45}$ As classificações em termos de minzu revelam que para Fu Yunlong as identidades étnicas e raciais não correspondiam ao nacionalismo e ao estatismo, mas eram fluidas. ${ }^{46}$ Ao tentar colocar ordem na diversidade da população brasileira, $\mathrm{Fu}$ Yunlong não dispunha do vocabulário ou da memória das ideologias raciais e eugênicas brasileiras para descrever identidades raciais tais como "mulato". Ele incluiu libertos negros, cuja alforria os transformara em minzu, como cidadãos e, portanto, membros do corpo

44 Yunlong, "Carta para Li Hongzhang”, pp. 387-388.

45 Yunlong, "Baxi feng su".

46 Para uma análise das visões emergentes do "povo" (guomin-minzu) e dos esforços para transformá-los em um "povo nacional ativo" nos discursos finais do Qing, consulte Karl, Staging the World, pp. 117-148. 
nacional. Ele não deu atenção ao lugar dos chineses na hierarquia de castas raciais vigente no Brasil; em vez disso, criou uma categoria separada de minzu para os chineses no cenário brasileiro. Ele estava engendrando uma nova leitura da emergente consciência nacional chinesa, que entrelaçava a compreensão de minzu com memórias circum-oceânicas de formação racial, incluindo a transferência processual de ideologias raciais coloniais para novas formas de nacionalismos culturais assentes na raça.

Em uma missão ao Brasil em 1889, ele reconheceu que o povo chinês estrangeiro era bastante migratório; que eles se moviam ao longo de uma vasta rede diaspórica chinesa em busca de melhores oportunidades econômicas. Por exemplo, seus escritos sobre encontros com os chineses que se estabeleceram no Rio de Janeiro revelam que, a certa altura, havia mais de mil colonos na cidade, mas esse número havia se reduzido para aproximadamente duzentos em $1889 .{ }^{47}$ A diminuição da população chinesa transmitiu uma imagem do Brasil como uma parada temporária dentro de uma rota mais ampla, que conectava Cuba, Peru, São Francisco e outros lugares, atestando padrões de migração serial que ocorriam quando as oportunidades econômicas locais cessavam ou estavam sendo usurpadas. ${ }^{48}$ Entre os chineses que permaneceram no Rio, alguns abriram negócios como estabelecimentos para vender mantimentos ou restaurantes. ${ }^{49}$

Para Fu Yunlong, o desenvolvimento de um forte senso de nacionalismo chinês unificaria os chineses que viviam longe da China. Manter laços patrióticos com a China também significava garantir contribuições econômicas para a nação, mesmo dos trabalhadores em países estrangeiros. O diplomata Xue Fucheng observou que os chineses que moravam em São Francisco já enviavam milhões de dólares para a China a cada ano. Se continuassem enviando remessas nessa quantidade, a população residente no exterior cobriria o déficit comercial do país. ${ }^{50}$ Embora a China tenha se beneficiado com o recebimento dos ganhos dos chineses no

47 Fu Xuncheng (comp.), Fu Yunlong Riji [O diário do Fu Yunlong], Hangzhou: Zhejiang guji chu ban she, 2005, pp. 212-215.

48 Lok Siu, "Serial Migration: Stories of Home and Belonging in Diaspora", in Sukanya Banerjee, Aims McGuinness e Steven Charles McKay (eds.), New Routes for Diaspora Studies (Bloomington: Indiana University Press, 2012), pp. 143-173; Young, Alien Nation.

49 Xuncheng, Fu Yunlong Riji, pp. 212-215.

50 Wang, In Search of Justice, p. 43. 
exterior, esses planos se mostraram desfavoráveis a todos os países anfitriões e serviram como material para estimular o sentimento antichinês.

Fu Yunlong não era o único a elaborar planos de expandir os objetivos políticos e econômicos da China para o Brasil; o proeminente estudioso e pensador político chinês Kang Youwei compartilhou visões semelhantes sobre este país. Em 1895, a China, enfraquecida por muitos fatores, incluindo guerras, começou a ceder territórios a potências estrangeiras. Kang Youwei, um reconhecido intelectual chinês e figura importante no desenvolvimento do Estado chinês moderno, estava preocupado com a possibilidade de a civilização chinesa em breve ser extinta. Para ele, o Brasil oferecia uma possível solução para preservá-la, onde imigrantes chineses poderiam construir uma nova China. ${ }^{51}$ As ideias coloniais sobre embranquecimento racial influenciaram as noções racializadas de identidade nacional de Kang Youwei e criaram um paradoxo. Como observa Liang Zhan, por um lado, Kang Youwei acreditava que os emigrantes chineses poderiam criar uma nova China no Brasil; por outro lado, o projeto de embranquecimento ameaçava assimilar os chineses a ponto de sua extinção. ${ }^{52}$ Embora a ideologia de embranquecimento racial fosse um fator principal, os abolicionistas brasileiros temiam que os chineses caíssem em mãos de vorazes defensores da escravidão, que os explorariam sem prestar contas. No final da era Qing, o governo estava fraco demais para estender sua proteção política aos chineses estrangeiros no Brasil. Os imigrantes japoneses se tornaram uma opção favorável, pois o governo Meiji era poderoso e poderia investir no Brasil por meio da injeção de recursos em assentamentos permanentes para japoneses no exterior. ${ }^{53}$

51 Liang Zhan, "Wenming, lixing yu zhongzu gailiang: yige Datong shijie de gouxiang [Civilização, racionalidade e melhoria racial: o plano de um mundo de grande unidade]", in Lydia H. Liu (ed.), Shijie zhixu yu wenming dengji [Ordem mundial e hierarquia da civilização] (Shanghai: Sanlian Chubanshe, 2016), pp. 142-147.

52 Zhan, "Wenming, lixing", pp. 142-147.

53 No início do século XX, as condições sombrias da vida nas plantações e os escassos ganhos forçaram o governo japonês a reformular seus planos de emigração - ver Hirochika Nakamaki, “Aliança Colony”, in Japanese Overseas Migration Museum [catálogo de exposição] (Yokohama: Japanese International Cooperation Agency, 2004), p. 23. O governo japonês começou a investir em colônias permanentes no Brasil baseadas no "cultivo" de indivíduos. Na década de 1920, com a ajuda de associações de emigração da prefeitura e da organização privada Rikkō Kai, migrantes japoneses das prefeituras de Nagano, Tottori e Toyama fundaram a Colônia 
O sonho de construir uma nova China no Brasil também aparece nos escritos do diplomata chinês Liu Shixun. Ele visitou o Brasil em 1909, um ano após o início oficial da imigração japonesa para o Brasil, em 1908, atestando o contínuo interesse chinês em investigar a expansão econômica e política japonesa por meio de esquemas de migração. Ele considerou uma pena que a China ficasse sentada assistindo ao Japão tomar terras no Brasil, onde os japoneses cultivavam com sucesso arroz, feijão, café e outros produtos. ${ }^{54}$ Liu viajou ao Brasil em uma missão especial para estabelecer relações diplomáticas entre o Brasil e a China, o que na verdade implicava interesse mútuo em estabelecer tratados comerciais, que incluíam o redirecionamento da migração chinesa da América do Norte para a América do Sul. ${ }^{55}$ Liu, juntamente com uma delegação de diplomatas chineses, visitou o Rio de Janeiro, Petrópolis, São Paulo e Santos para avaliar as perspectivas de assentamento chinês. Em 1914, Liu estabeleceu a primeira delegação chinesa no Rio de Janeiro. Logo depois, o diplomata Wu Guangzhuo, em apoio aos objetivos de Liu para a imigração chinesa no Brasil, enviou um relatório ao Ministério do Interior chinês. As missivas de Wu ecoavam as opiniões do governo Meiji sobre a migração como um modo de expansão econômica e política. Em uma correspondência datada de 29 de janeiro de 1918, Wu defendeu o envio de trabalhadores chineses ao Brasil. ${ }^{56}$ Ele argumentou que a eclosão da Primeira Guerra Mundial fez com que muitos imigrantes europeus retornassem aos seus países para servir na guerra e que, ao final desta, as nações europeias que necessitavam de trabalhadores exigiriam que os migrantes retornados permanecessem, exacerbando a escassez de mão de obra no Brasil. Elogiando o sucesso da imigração e colonização japonesas em São Paulo, Wu observou que havia espaço para a China replicar esses esforços, uma vez que a falta de mão de obra na Europa forneceria inesperadamente os meios para os trabalhadores

Aliança no estado de São Paulo, com o slogan "cultivar indivíduos capazes em vez de cultivar café e plantas” (Nakamaki, "Aliança Colony”, p. 23).

54 Qi Yaolin, Xunling: Jiangsu sheng zhanggongshu xunling di sanbaibashiyi hao Jiangsu Sheng Gongbao 1485 [Ordem do Escritório Executivo da Província de Jiangsu No. 381, Diário da Província de Jiangsu, de 29 de janeiro de 1918], tradução de Wang Siwei, [China]: [s. n.], 1918, pp. 3-6.

55 Carlos Francisco Moura e Liou Shi-Shun, Plenipotenciário do Império da China: viagem ao Brasil em 1909, Macau: Instituto Internacional de Macau, 2011, p. 33.

56 Yaolin, Xunling, pp. 3-6. 
chineses se estabelecerem no Brasil, alcançando assim a meta da economia: expansão. Como os imigrantes japoneses se limitaram a se estabelecer no estado de São Paulo, Wu usou esse ponto para enfatizar as possibilidades de direcionar o yizhi chinês (imigração-colonização) para outros estados, como Bahia, Minas Gerais, Rio de Janeiro, Paraná e Rio Grande do Sul. ${ }^{57}$

Figura 2 - Centro Social Chinês do Rio de Janeiro, 13 de dezembro de 2015

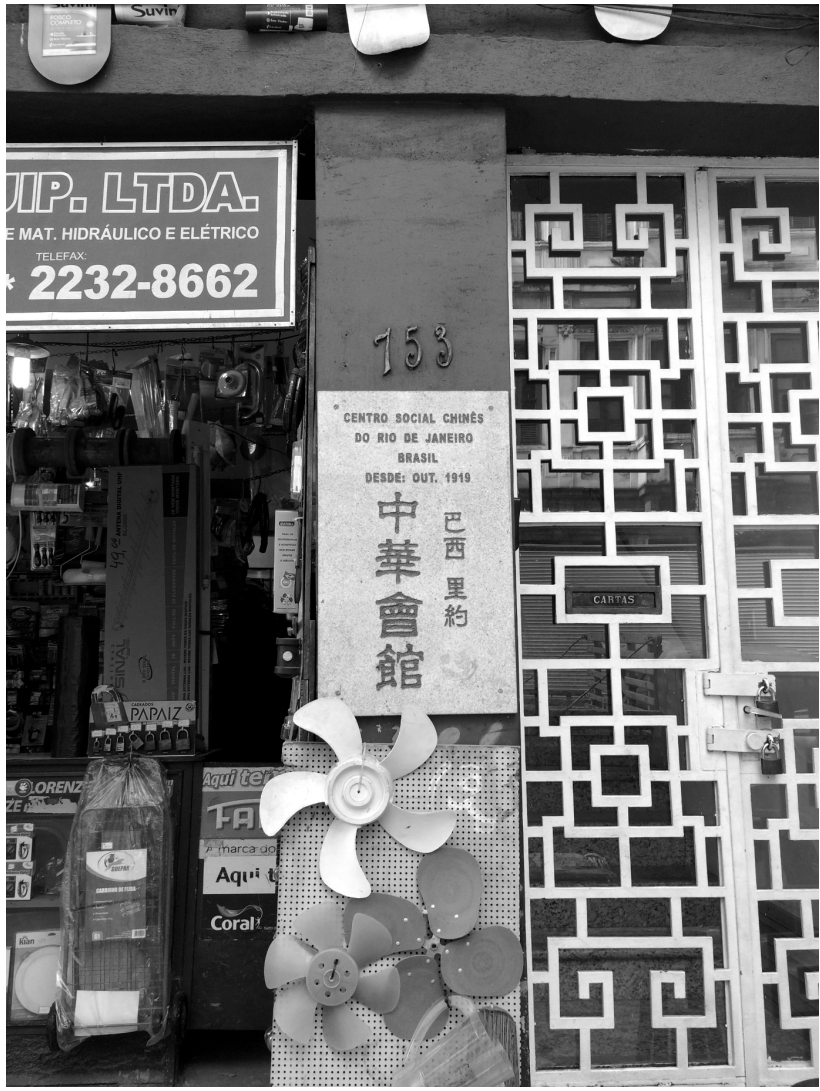

Fonte: Fotografia da autora.

57 Ordem do Chefe do Executivo da Província de Jiangsu (n. 381), de 29 de janeiro de 1918. Título: "Permita que o Ministério do Interior promova o projeto de plantação de imigração depois que [o Ministério do Interior] consultar nosso representante no Brasil, que enviou cartas para pedir que o trabalhador migrante atenda à necessidade de trabalho resultante da Guerra da Europa [Primeira Guerra Mundial]". Yaolin, Xunling, pp. 3-6. 
As tentativas diplomáticas de promover o trabalho chinês foram bem-sucedidas, mas em um grau bem menor do que o esperado. Pequenas ondas de imigração chinesa para o Brasil ocorreram ao longo do século XX. Os imigrantes se estabeleceram em lugares como Rio de Janeiro e São Paulo, como evidenciado pelo estabelecimento de vários centros de assistência social e culturais. Por exemplo, em 1919, cerca de 100 comerciantes e empresários, incluindo donos de restaurantes e lavanderias, estabeleceram o Centro Social Chinês do Rio de Janeiro (Figura 2), localizado próximo ao centro da cidade. Hoje, seus membros mantêm fortes laços com o governo de Taiwan. ${ }^{58}$ Por fim, os interesses dos estadistas chineses em replicar a escala do modelo de migração e assentamento do Japão no Brasil não foram realizados.

Essas identidades nacionais racializadas também informaram uma consciência nacional chinesa emergente que prevaleceu entre os líderes dos círculos nacionalistas e do Partido Comunista Chinês ao deliberar o futuro da China. O movimento em direção à unificação nacionalista étnica chinesa significou uma rejeição ao imperialismo de nações estrangeiras e ao Império Qing da Manchúria, que colonizara o povo chinês Han. ${ }^{59}$ Em 1924, Sun Yat-Sen proferiu os "Sanmin zhuyi" ("Três princípios do povo"), no qual questionou como poderia a China, com uma grande população e civilização antiga, com sua "raça pura e única", ter sido vítima de tal indignidade: "O resto do mundo é a faca e a travessa, enquanto somos o peixe e a carne. Nossa posição agora é extremamente perigosa... enfrentaremos uma tragédia - a perda de nosso país e a destruição de nossa raça". ${ }^{60}$ No mesmo ano, Li Dazhao, cofundador do Partido Comunista Chinês, condenou a supremacia branca e a hegemonia cultural ocidental, repudiando "os povos brancos como pioneiros da cultura no mundo; eles se colocam em uma posição superior e olham para outras raças como inferiores". ${ }^{61}$

58 Sandra Machado, "Chineses no Rio de Janeiro", MultiRio, 5 ago. 2014, <http://www.multirio. rj.gov.br/index.php/leia/reportagens-artigos/reportagens/795-os-chineses-no-rio-de-janeiro>, acessado em 4/5/2020.

59 Karl, Staging the World, p. 118.

60 Sun Yat-Sen, "San Min Zhuyi [Três princípios do povo]", World History Commons, <https:// worldhistorycommons.org/sun-yat $\% \mathrm{E} 2 \% 80 \% 93$ sen-three-principles-people>, acessado em $5 / 3 / 2020$.

61 Li Dazhao apud David Scott, China and the International System, 1840-1949, New York: Suny Press, 2008, p. 217. 


\section{Abolição e culturas visuais da sinofobia}

No Brasil, existiam visões ambíguas em relação aos chineses, e termos como "raça amarela", "trabalho amarelo" e "raça coolie" eram usados alternadamente nas discussões sobre a mão de obra chinesa. Os opositores ecoavam a retórica que circulava nos Estados Unidos de que os chineses trariam novas formas de trabalho precarizado e explorado; enquanto isso, defensores do emprego de trabalhadores chineses, como o Barão de Cotegipe, favorável à escravidão, defendiam o trabalho chinês exatamente pelas mesmas razões. Líderes políticos, intelectuais, escritores e artistas brasileiros criaram representações raciais da China para participar de debates políticos e econômicos sobre o trabalho chinês.

A produção cultural brasileira do século XIX está repleta de representações de funcionários Qing (os mandarins) e trabalhadores chineses. Tais construções culturais da chinesidade tiveram um papel crítico na produção de maneiras de ver os chineses enquanto uma raça. O historiador jurídico Hoang Gia Phan argumenta que a construção dos chineses enquanto uma raça assume uma lógica que "codifica 'raça' como "cultura"". ${ }^{2}$ Essa codificação dos chineses enquanto raça inventou a forma do asiático como uma "raça radical", ou seja, a forma asiática funcionou como uma alternativa ao binário legal entre trabalho livre e trabalho escravo. ${ }^{63}$ Os intelectuais brasileiros não estavam produzindo projetos nacionais miméticos ou derivados dos da América do Norte ou da Europa, mas os debates sobre a chamada "questão chinesa" mostram que as preocupações teóricas sobre a nação tornaram-se estruturalmente conectadas aos debates globais sobre concorrência entre mão de obra e políticas anti-imigratórias relacionadas.

62 Phan, “'A Race So Different”, p. 133.

63 Phan, “AA Race So Different”, p. 133. 
Figura 3 - "Plantation chinoise de thé, dans le Jardin Botanique de Rio-Janeiro", de Rugendas ${ }^{64}$

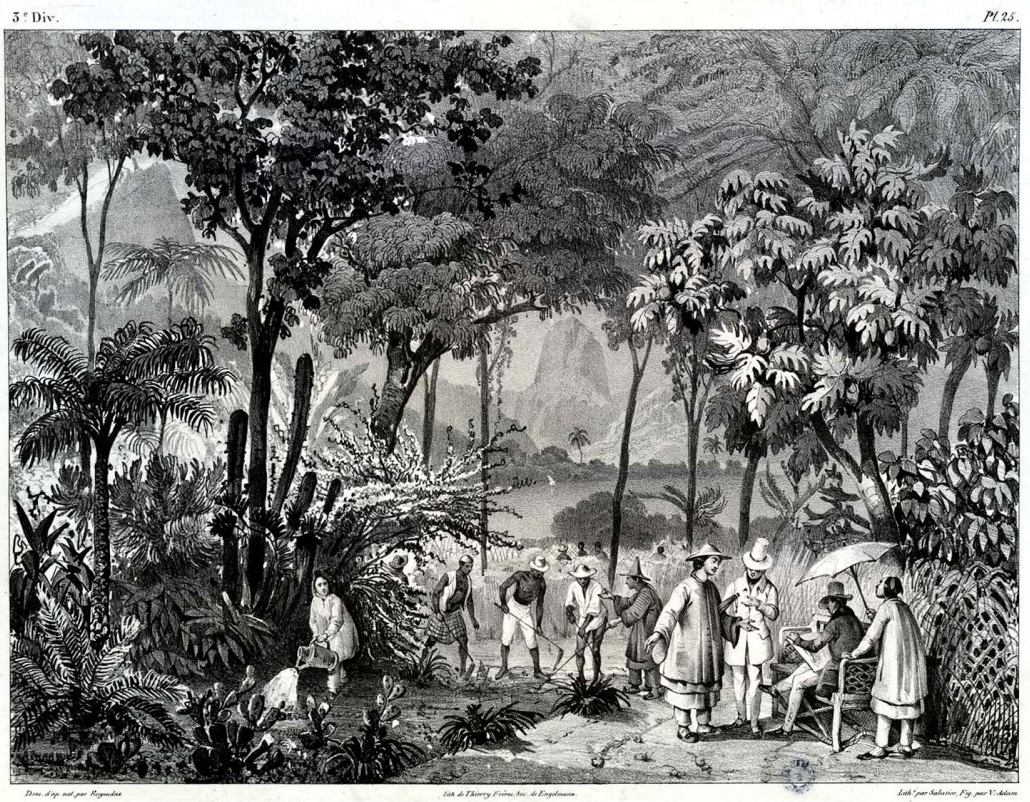

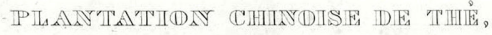
dans le Jardin Botanique de Rio.Janeiro.

O artista alemão Johann Rugendas (1802-1858) realizou uma das primeiras representações visuais de trabalhadores chineses no Brasil. ${ }^{65}$ As ilustrações de Rugendas tiveram um papel determinante na construção da terra e do povo do Brasil como um local onde se realizavam fantasias sobre riquezas e mão de obra coloniais. No cenário dramático do Pão de Açúcar (Figura 3), a cena retrata a exuberante paisagem tropical do Rio de Janeiro pré-industrial e mostra uma imagem complexa de uma potencial aliança econômica Qing-Portuguesa para estabelecer o cultivo de chá e a imigração de mão de obra chinesa. Roupas e acessórios diferenciam os corpos europeus, asiáticos e africanos, e servem como símbolos visuais dos tipos raciais europeus e asiáticos produzidos através de uma lógica

64 Johann Moritz Rugendas, "Plantation chinoise de thé, dans le Jardin Botanique de Rio-Janeiro", in Malerische Reise in Brasilien von Moritz Rugendas (Paris: Engelmann, 1835), <http:// acervo.bndigital.bn.br/sophia/index.asp?codigo_sophia=6194>, acessado em 10/5/2020.

65 Rugendas, "Plantation chinoise de thé". 
da cultura. Os senhores europeus estão usando cartolas e casacos. A ilustração de Rugendas confunde roupas, acessórios e penteados tradicionais masculinos Qing com os femininos ao codificar trabalhadores masculinos chineses com atributos femininos, como roupas e penteados. O efeito simboliza visualmente a posição subserviente dos plantadores chineses masculinos. A ilustração também impregna os chineses com atributos de uma outra época. Segurando o guarda-sol para o cavalheiro europeu está a figura de um corpo asiático, retratado com um coque de cabelo e um robe de seda solto. Esse penteado poderia ter sido comum entre os homens que viviam durante a dinastia Ming (1368-1644), mas não teria lugar durante a dinastia Qing (1644-1911), quando os homens tiveram que usar a trança Qing. Cortar a trança significava desafiar a dinastia Qing e trazia graves repercussões, como pena de morte. No canto inferior esquerdo, um homem da nobreza Qing encontra-se entre um grupo de trabalhadores negros, enquanto gesticula didaticamente no chão. O retrato de Rugendas da plantação de chá chinesa mostra uma hierarquização entre a nobreza Qing e o trabalhador chinês, bem como camadas sobrepostas de racialização. A nobreza Qing está entre os europeus, talvez membros da corte imperial brasileira, enquanto os trabalhadores chineses lavram ao lado de escravos africanos. Embora os chineses estejam ao lado de europeus e africanos, seus trajes e penteados os levam a uma era e lugar distantes, que estão fora de sincronia com o momento em que foi produzida a imagem.

As cenas que transferem os regimes raciais da escravidão também aparecem nos escritos e nas ilustrações de viagens do diplomata Henrique Carlos Ribeiro Lisboa, que escreveu um relato detalhado de sua missão especial na China em 1880 e depois publicou alguns de seus escritos em A China e os chins: recordações de viagem. ${ }^{66}$ Lisboa escreveu sobre os chineses em uma história relacional e global de raça e racialização, que ganhou nova forma durante a consolidação de um sistema global de estados-nações e categorias nacionais racializadas correspondentes.

Além dos relatos escritos de Lisboa, o livro contém uma série de ilustrações, incluindo um mapa e 44 impressões. Os relatos e as ilustrações

66 Henrique Carlos Ribeiro Lisboa, A China e os chins: recordações de viagem, Montevideo: Typographia a vapor de A. Godel, 1888. 
de Lisboa apresentam uma narrativa enganosamente realista sobre a terra e o povo da China; são meticulosos sobre uma variedade de tópicos, desde agricultura, indústria, religião, ciência e arte até a composição étnica da China. No capítulo "Raças, caráter e costumes", Lisboa apresenta um relato etnográfico de várias etnias chinesas, intitulado "Tipos de habitantes da China", que inclui uma ilustração de seis homens retratados com roupas e características distintivas, como chapéus e estilos de cabelo. Abaixo de cada figura, há uma legenda que indica sua etnia: "Manchu, Mongol, Punti, Hakka, Hialo e Tankia". ${ }^{67}$ Através deste exemplo e de outros, Lisboa tenta invalidar a ideia generalizada de que todos os chineses pertenciam à raça mongol. No período dessa publicação, expressões como "raça mongol" alimentavam o medo do risco amarelo. Palavras como "mongol" evocavam figuras poderosas e invencíveis, como Genghis Khan, mas o termo mongolismo era usado para sinalizar doenças congênitas. ${ }^{68}$ Tais equívocos, ou, nas palavras de Lisboa, "opiniões vulgarizadas" e "erros grosseiros”, podem ter se originado desde o século XIII, nos relatos do comerciante veneziano Marco Polo sobre suas visitas à China, enquanto esta estava sob o domínio do Império Mongol. ${ }^{69} \mathrm{O}$ objetivo de Lisboa era desmerecer noções unidimensionais de longa data sobre os chineses, mas seus escritos sobre a China, feitos no contexto de uma missão diplomática de coleta de informações, nomeiam, classificam e categorizam obsessivamente os chineses em tipos étnico-raciais.

Embora Lisboa tentasse desmistificar estereótipos, ele não conseguia considerar os chineses como iguais aos europeus. Ele os situou no campo do que Mary Louise Pratt chama de "o olhar imperialista". ${ }^{70}$ Seus relatos eram característicos dos projetos etnográficos do século XIX, que decididamente contribuíram para os arquivos da imaginação colonial, os quais, Appadurai observa, eram inegavelmente "classificatórios, taxonômicos, penais e somáticos". ${ }^{71}$ No contexto de mudança da ordem

67 Lisboa, A China, p. 284.

68 Michael Keevak, Becoming Yellow: A Short History of Racial Thinking. Princeton: Princeton University Press, 2011, pp. 3-8.

69 Lisboa, A China, p. 275.

70 Mary Louise Pratt, Imperial Eyes: Travel Writing and Transculturation, New York: Routledge, 2007.

71 Arjun Appadurai, “The Colonial Backdrop", Afterimage, v. 24, n. 5 (1997), p. 1. 
mundial no pós-abolição, de transição para novas formas de trabalho migrante precário e de estruturação de um sistema global de estados-nações, Lisboa estava teorizando o lugar do Brasil dentro de categorias nacionais racializadas, constituídas globalmente. O tratamento ambíguo dispensado por Lisboa aos chineses, ora como imigrantes assimiláveis, ora como excluídos, era sintomático dos pontos de vista existentes sobre estes consolidarem ou enfraquecerem uma ordem simbólica nacional.

O capítulo "Emigração chinesa" fornece uma análise detalhada da migração na China e no exterior. Lisboa especificou que esta última tinha duas naturezas: trabalho contratado e trabalho livre. Ele explicou que o trabalho contratado ou o "tráfico amarelo" produzia as mesmas condições deploráveis que ocorreram com a escravidão africana, e depois denunciou as atrocidades do comércio de escravos como "crimes da civilização ocidental" e colonização europeia. ${ }^{72} \mathrm{O}$ capítulo inclui uma cena ilustrada, intitulada "A sangria de cúlis na América" (Figura 4), que racializa os trabalhadores chineses, retratando-os como animais, de forma semelhante às representações raciais de escravidão e negritude do cenário de Rugendas em "Negros no fundo do porão". A cena no relato de Lisboa mostra dezenas de vítimas de tráfico amarelo em frente a uma fazenda. Homens vestindo roupas de estilo europeu sentam-se em uma varanda acima do nível do chão. Duas figuras gordas olham para grupos de homens nus em cativeiro, cujos braços e pernas estão amarrados de forma que seus membros estão terrivelmente contorcidos. No canto direito, posiciona-se um supervisor vestido com casaco, calça e chapéu de estilo europeu. Ele segura uma faca e parece estar prestes a cortar a mão de uma mulher retratada com características étnicas distintas, um coque de cabelo e uma camisa de botão. Roupas e penteados tornam-se marcadores culturais que diferenciam o status de classe entre o trabalhador e o supervisor racializado e etnificado.

Lisboa tomou partido dos abolicionistas e, portanto, opôs-se ao trabalho coolie, que era incompatível com a crença no branqueamento e no trabalho assalariado. Por meio deste relatório e ilustrações, Lisboa tentou oferecer aos leitores da elite brasileira outra perspectiva sobre a questão global chinesa. ${ }^{73}$ Para ele, a questão do futuro do Brasil

72 Lisboa, A China, p. 333.

73 Lisboa, A China. 
como nação não era apenas considerar se a chamada raça amarela seria adequada para os objetivos de embranquecer a composição racial da república emergente. Ele instou os leitores a debater as economias escravistas que formaram a base do poder econômico e político brasileiro, e alertou sobre a insustentabilidade da dependência constante do trabalho escravo, cuja continuação levaria à crise econômica. ${ }^{74}$ Não é por acaso que ele publicou seu livro em 1888, mesmo ano em que o Brasil declarou a emancipação de todos os escravos e começou a procurar novas fontes de trabalho na Europa, Ásia e Oriente Médio. Por fim, para Lisboa, liberdade e trabalho livre não eram possibilidades se a economia e a estrutura social da plantação continuassem sendo a fonte da riqueza e do poder da Primeira República.

Figura 4 - "A sangria de cúlis na América (Desenho chinês)"75

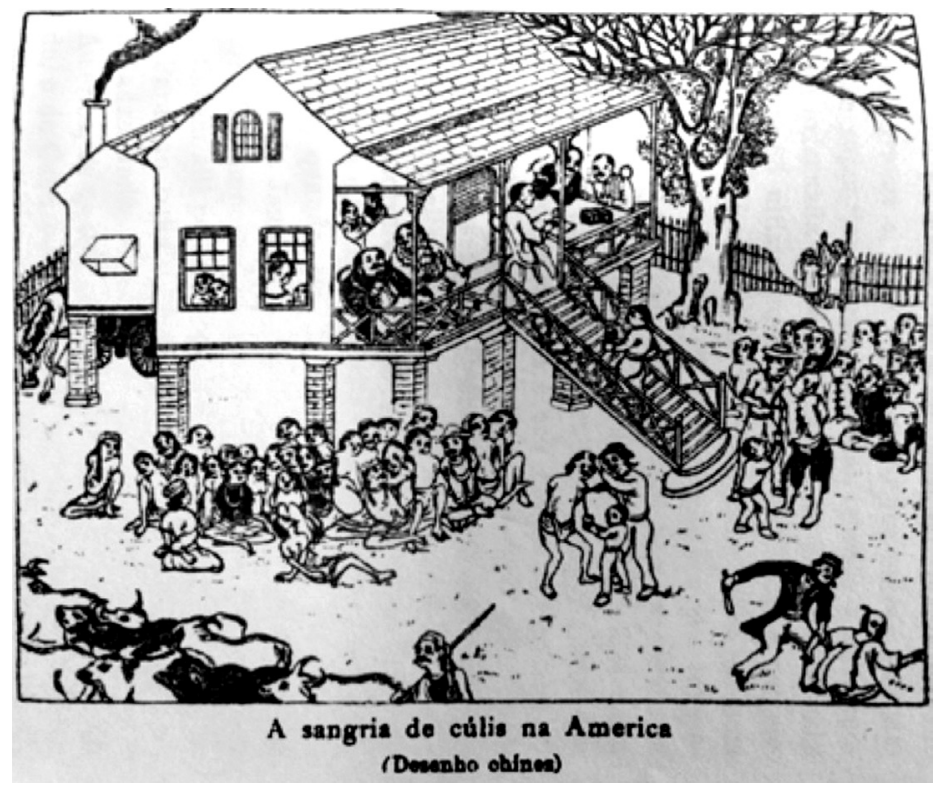

74 Lisboa, A China, pp. 370-371.

75 Lisboa, A China, p. 345. 
Obscurecendo a linha entre arte e política, os colaboradores da Revista Ilustrada, com sede no Rio de Janeiro, responderam à imigração chinesa de uma maneira que lança luz sobre o surgimento de uma nova consciência política em relação a raça, liberdade e cidadania nacional. Fundada em 1876, a revista, amplamente lida, teve duração de 21 anos, publicando seu último número em $1897 .^{76}$ A Revista Ilustrada usou o humor para apresentar e comentar os eventos mais proeminentes do dia. Angelo Agostini, imigrante italiano do Piemonte, foi o fundador da revista e o artista responsável pela maior parte de suas ilustrações. Seus colaboradores incluíam nomes eminentes da tradição literária brasileira, como Machado de Assis e Artur de Azevedo. ${ }^{77}$ Estes foram aclamados e bem vistos em seus dias, reforçando a reputação e a popularidade da revista. Sátiras, cartuns e escritos políticos nos permitem ver como artistas e escritores implantaram representações raciais da chinesidade para se opor aos sentimentos pró-escravidão da elite colonial, cujas agendas muitas vezes não coincidiam com o bem-estar do público em geral. Espalhadas por diferentes edições da Revista Ilustrada estão caricaturas de trabalhadores chineses e funcionários do Qing. Eles aparecem entre as ilustrações do índio e do escravo. Alegoricamente, a indigeneidade representa o território colonial, que deve ser liberado e esvaziado para que os imigrantes recém-chegados se estabeleçam e constituam um Estado independente. A negritude personifica a escravidão, e a masculinidade incorpora o trabalho precário. Tais eram os Outros antitéticos que representavam barreiras à liberdade e à nação.

76 A Revista Ilustrada totalizou aproximadamente 740 edições numeradas, além de publicações adicionais.

77 Osmar Pereira Oliva, "Machado de Assis, Joaquim Nabuco, Eça de Queirós e a imigração chinesa: qual medo?", Revista da Anpoll, v. 2, n. 24 (2011), pp. 65-84. 


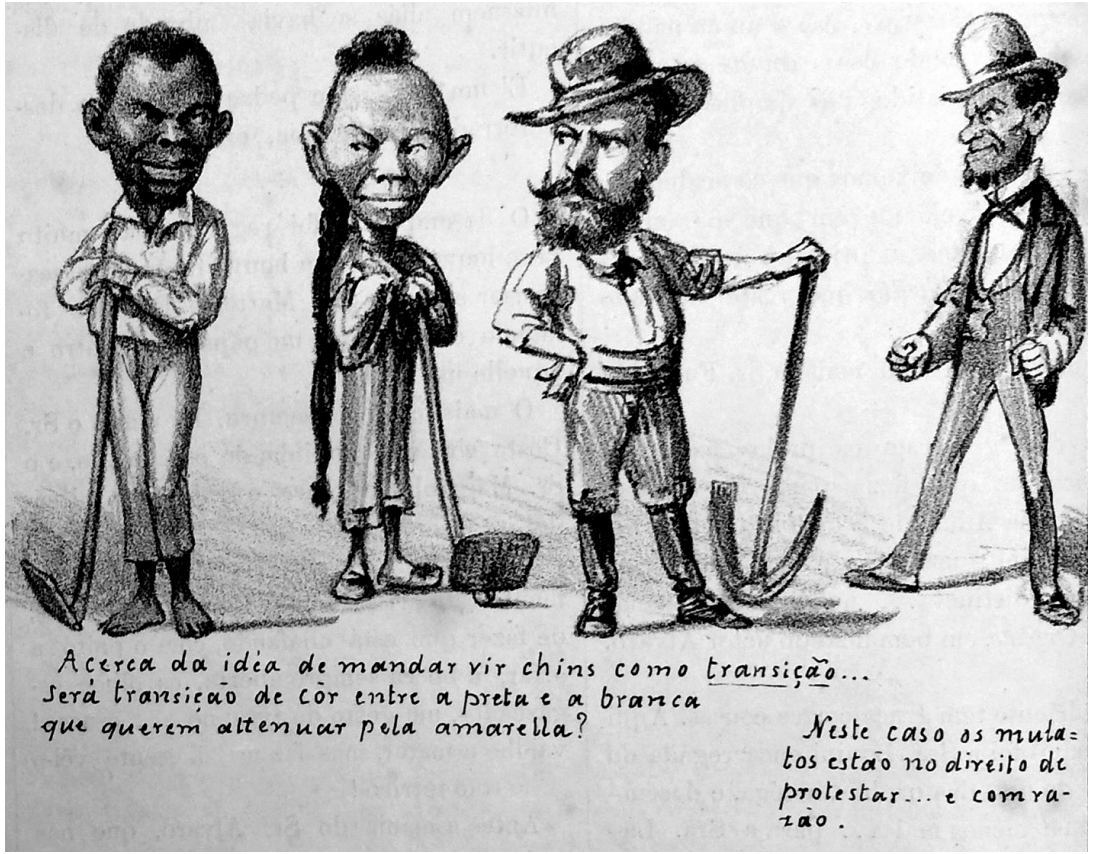

A ilustração "China em transição" (Figura 5) defendia a ideia de que, em vez de ajudar a branquear o Brasil, os chineses transformariam o país em uma raça predominantemente amarela. Quatro caricaturas de um escravo negro, um trabalhador chinês, um agricultor branco e um mulato - transmitem a ideia de que os chineses agiriam como uma ponte econômica e racial entre negritude e brancura. A imagem da Revista Ilustrada é exemplar da semiótica visual da raça que se desenvolveu durante o século XIX. Essa imagem mostra que os chineses podiam substituir os mulatos, servindo como intermediários entre negros e brancos. Os chineses poderiam "diluir" as "interferências negativas" do escravo negro, facilitando assim o processo de criação de um Brasil mais leve e livre. Pode-se ler nas legendas: "No que diz respeito à ideia de trazer o chinês aqui como uma transição... será a transição da cor entre preto e branco em direção a um tom amarelo? Nesse caso, 
os mulatos têm o direito de protestar... e com razão". ${ }^{79}$ Ao lado está o desenho de um mulato indignado, com a legenda a apontar seu direito de protestar contra a imigração chinesa - pois "o que acontecerá com ele?". Embora o texto explique didaticamente essa ideia, a imagem produz seu próprio argumento sobre a miscigenação, que não depende da alfabetização. A miscigenação chinesa torna-se visualmente codificada como uma ameaça à figura mulata, a ponte ideológica entre negritude e branquitude. O desenho do mulato furioso é uma afirmação clara de que o trabalho chinês traz consigo a ameaça viril dessa sexualidade que poderia transformar todos biologicamente em uma raça amarela a personificação de uma nova classe de trabalhadores precários.

Figura 6 - "A Colonização chinesa", $1883^{80}$

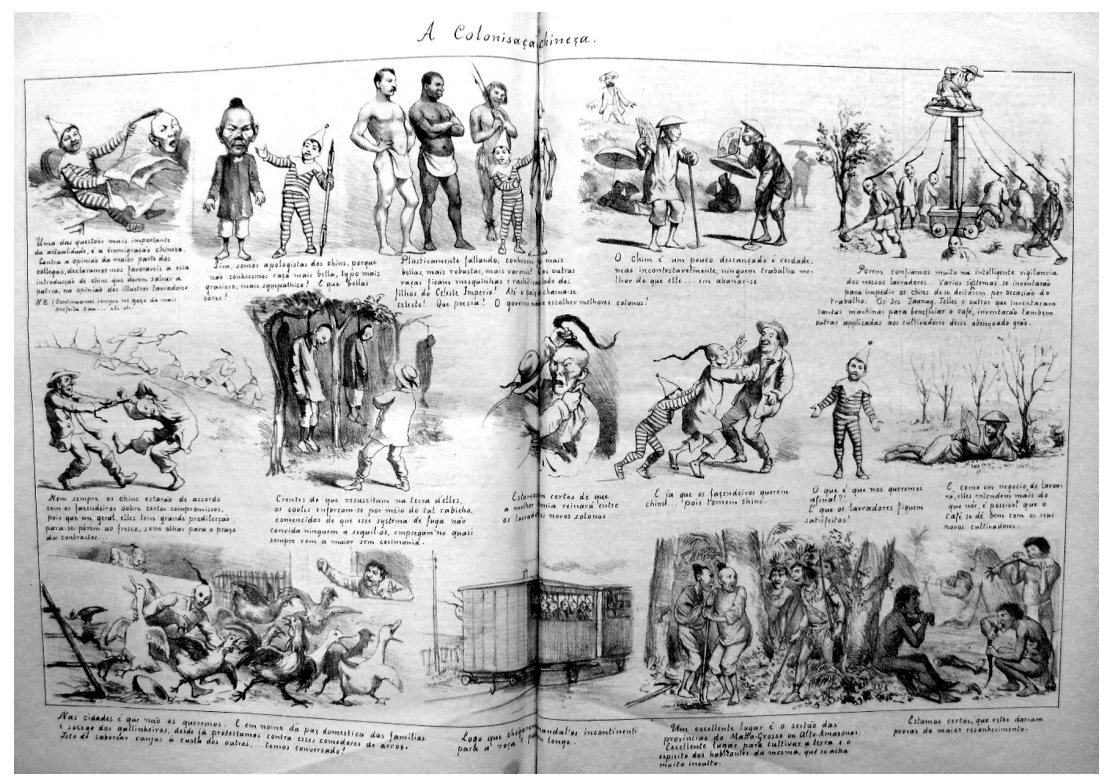

79 Revista Ilustrada, n. 120, 1878, p. 8.

80 Revista Ilustrada, n. 358, 1883, pp. 4-5. 
O desenho intitulado "A colonização chinesa" (Figura 6) desaconselha a miscigenação racial e cultural com os chineses, alertando que o trabalho chinês só contribuiria para o agravamento de problemas já existentes no Brasil. Enquanto as imagens recomendam cautela com relação aos efeitos negativos do trabalho chinês, elas também fornecem um olhar crítico da história colonial do Brasil. As figuras indígenas retratam um Brasil canibal e doente, que literalmente come os chineses. O trabalho chinês é mostrado como precário, não confiável e não gratuito. Um quadro mostra trabalhadores chineses que cometeram suicídio. Outro os descreve roubando animais de fazenda, retratando o medo de que eles levem embora a riqueza local. No entanto, os cartuns apresentam um argumento crítico contra os agricultores, apresentados como escravocratas; um destes fica acima de um círculo de chineses cujas tranças foram amarradas a um poste. Eles são acorrentados enquanto são forçados a trabalhar no campo. Coletivamente, essas imagens configuraram os corpos asiáticos, africanos e indígenas como a antítese da liberdade: a moeda para as transações de esquecimento e exclusão embutidas nas promessas nacionais de liberdade. ${ }^{81}$

81 Mae Ngai, ao discutir a relação entre cidadania, raça e nacionalidade, afirma que as fronteiras do estado-nação são solidificadas por meio de atos de exclusão forjados contra "sujeitos impossíveis", como imigrantes ilegais. Para Ngai, a ideia do sujeito impossível refere-se a processos de racialização que colocam grupos étnicos no lugar do estrangeiro permanente. O Estado vê esses "cidadãos estrangeiros" como inassimiláveis ao corpo político nacional, uma vez que o sujeito impossível é "uma pessoa que não pode ser e um problema que não pode ser resolvido". Ver Mae Ngai, Impossible Subjects: Illegal Aliens and the Making of Modern America, Princeton: Princeton University Press, 2004, p. 5. 


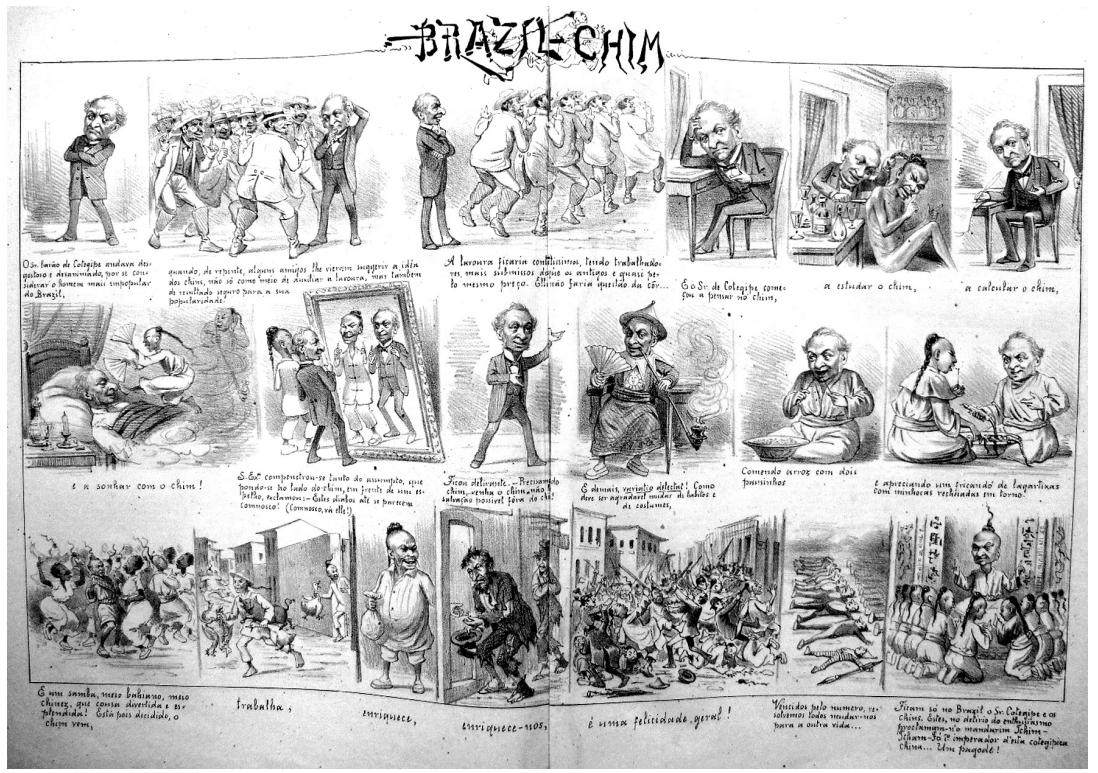

Publicada seis meses após a Lei Áurea abolir a escravidão, a ilustração intitulada "Brazil-chim" (Figura 7) ("chim" se refere aos trabalhadores migrantes chineses) aborda a questão, então atual, da exploração do trabalho chinês e transmite a visão de que os chineses transformarão o Brasil em um híbrido degenerado de Brasil e China. O primeiro quadro da terceira fila introduz visualmente o público brasileiro na questão chinesa global ao apresentar a ideia de que os chineses não branqueariam o país. Em vez disso, eles seriam assimilados pela população afro-brasileira. As imagens mostram homens chineses que enlouqueceram ao dançar samba. Suas tranças incontroláveis e eretas emitem uma mensagem política e sexual enquanto dançam de forma imprudente com mulheres baianas. A legenda diz: "Esses sambais são meio baianos, meio chineses, que coisa divertida e esplêndida. Bem, está decidido. O chinês virá". ${ }^{83}$ No entanto, o texto funciona de forma secundária à imagem visual.

83 Revista Ilustrada, n. 523, 1888, pp. 4-5. 
A cena do chinês sambando é uma representação sarcástica de uma atividade moralmente suspeita. Aqui, os códigos visuais do samba criam uma racialização sobreposta entre o chinês e a negritude. Da mesma forma, o próximo quadro fornece outro exemplo de contradição entre o que está escrito e o que é retratado. Um homem chinês é mostrado roubando animais, mas a legenda diz: "ele trabalha". ${ }^{84}$ Depois dessa cena, há a foto de um brasileiro branco empobrecido, implorando a um chinês corpulento por dinheiro, com a legenda: "os chineses nos enriquecerão". ${ }^{85}$ Os códigos visuais ofuscam poderosamente o texto escrito e mostram uma semiótica visual internacionalmente circulante que entrou nos debates brasileiros sobre a construção de nações.

Figura 8 - "Liberdade", $1888^{86}$

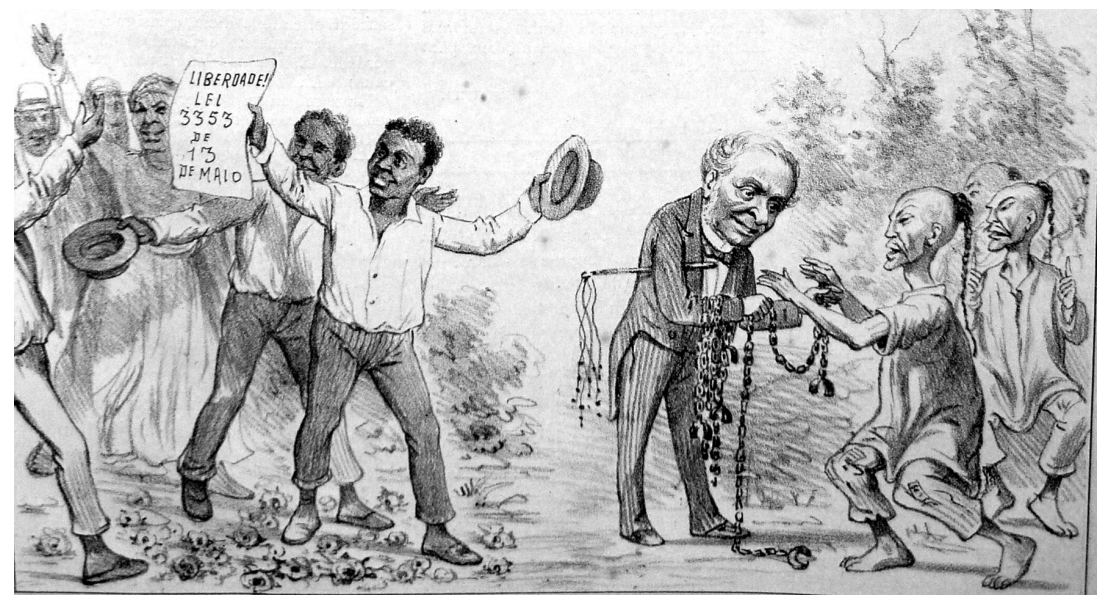

O último quadro da série mostra uma versão chinesa do Barão de Cotegipe, um zeloso antiabolicionista e chefe do Conselho de Ministros durante os últimos anos do Império brasileiro (1885-1888). Seu apoio ao trabalho precarizado também teve como objetivo manter a ordem aristocrática e preservar o poder imperial. Por seu desejo de receber chineses 
no Brasil, ele não escapa à visão de destino da miscigenação degeneradora, representada na aquisição de traços biológicos e étnicos chineses. Finalmente, a legenda adverte que o Brasil se tornará chinês se o Barão de Cotegipe conseguir estabelecer um esquema de migração laboral chinesa com tipos como o - ficcionalizado - mandarim Tchim-Tcham Fó. O Barão de Cotegipe, adverte a ilustração, transformará o Brasil em sua versão de uma China escravizada, "essa China de Cotegipe". ${ }^{87}$ Se esse empreendimento for bem-sucedido, o Brasil degenerará em direção a um híbrido Brasil-China, dificultando diretamente a formação de uma república liberal branca. A figura intitulada "Liberdade" (Figura 8), publicada em 11 de novembro de 1888, transmite literal e figurativamente a noção de que os trabalhadores chineses serviriam como substitutos da mão de obra negra escrava: escravos negros libertos aplaudem enquanto o Barão de Cotegipe algema os pulsos dos recém-escravizados.

\section{Brasil-China contemporânea}

As geografias imaginativas da China no Brasil ainda são relevantes hoje; as culturas visuais da exclusão chinesa mapeiam uma história da divisão internacional do trabalho, em que o capitalismo global destinou as economias extrativistas e que mais exploram a mão de obra para o sul global. A condição de alguns imigrantes chineses recém-chegados ao Brasil contemporâneo se assemelha muito facilmente aos casos do século XIX dos “coolies" chineses.

Investigações recentes descobriram uma rede liderada pela máfia chinesa de tráfico de trabalho humano entre o Brasil e a China. Em 2013, o Ministério do Trabalho Público (MPT) e o Ministério do Trabalho e Emprego (MTE) começaram a descobrir uma série de casos de escravidão chinesa no Brasil, em que migrantes chineses sem documentos chegam ao Brasil e são forçados a condições de exploração e trabalho cativo. ${ }^{\mathbf{8}}$ Desde setembro de 2015, o MPT e o MTE descobriram quatro casos

87 Revista Ilustrada, n. 522, 1888, p. 8.

88 "MPT e MTE flagram trabalho escravo em pastelaria do RJ", Ministério Público do Trabalho, 9 jul. 2015, <https://mpt.mp.br/pgt/noticias/mpt-e-mte-flagram-trabalho-escravo-em-pastelaria-do-rj>, acessado em 4/5/2020. 
somente no estado do Rio de Janeiro. Outros casos também apareceram no estado de São Paulo. Os fiscais do trabalho descobriram migrantes chineses sem documentos em condições de trabalho escravo em confeitarias de propriedade chinesa e outras pequenas empresas comerciais, como joalherias e lojas de acessórios. As investigações descobriram padrões semelhantes em todos esses casos, levando os fiscais do trabalho e a polícia a acreditar que existe uma rede liderada pela máfia chinesa facilitando o transporte de jovens chineses para condições de trabalho escravo no Brasil. O chefe chinês atrai jovens das províncias do sul da China com promessas de riqueza e aventura, então paga sua viagem ao Brasil e fornece documentos falsificados. Em troca, eles concordam em trabalhar no Brasil até que sua dívida seja paga. No entanto, em muitos casos, quando chegam ao Brasil, os empregadores retêm seus passaportes, os colocam em cativeiro e os forçam a viver e trabalhar em armazéns escondidos nos fundos das lojas. Os empregadores retêm o pagamento ou pagam apenas salários ínfimos, considerando que os trabalhadores estão pagando suas dívidas.

Em 2013, em Mangaratiba, Rio de Janeiro, um fiscal de trabalho encontrou um menor trabalhando diariamente das $5 \mathrm{~h}$ às $22 \mathrm{~h}$. Seu empregador o abusou fisicamente e o torturou com queimaduras de cigarro. O jovem conseguiu escapar e o denunciou ao MPT. ${ }^{89}$ Ele testemunhou contra seu empregador, que foi preso posteriormente, e entrou em um programa de proteção a testemunhas. Em 2014, o MPT e a Polícia Federal resgataram uma chinesa de 23 anos trabalhando em condição análoga à escravidão em uma loja de joias e acessórios de moda, localizada em Araçatuba, São Paulo. ${ }^{90}$ A mulher não podia sair da loja sem autorização. Ela dormia no depósito. Os proprietários lhe serviam comida no chão e ela bebia água de um balde. Em outro caso, os fiscais do trabalho resgataram dois homens chineses que os agentes encontraram trabalhando em condições de trabalho escravo. Dois meses após o resgate, eles voltaram aos seus antigos empregos. As jornalistas Eliane Lobato e Helena

"MPT e MTE resgatam chineses de trabalho escravo no Rio de Janeiro", Ministério Público do Trabalho no Rio de Janeiro, 13 abr. 2015, <http://prt1.mpt.gov.br/informe-se/noticias-do-mpt-rj/200-mpt-e-mte-resgatam-chineses-de-trabalho-escravo-no-rio-de-janeiro $>$, acessado em $4 / 5 / 2020$. 
Borges entrevistaram um dos trabalhadores sobre suas condições atuais, e ele argumentou que as condições haviam melhorado: ele agora sai para beber cerveja e visitar o shopping. Acima de tudo, no entanto, ele não queria voltar para a China. ${ }^{91}$ Sua resposta coloca em dúvida a reportagem sobre a escravidão chinesa no Brasil, pois ele afirma que trabalha de bom grado e até indica que desfruta de lazer e consumo de classe média. É impossível avaliar a partir dessa notícia a verdadeira natureza de sua resposta; mas, independentemente disso, essas histórias dão uma noção dos tipos de insegurança trabalhista que os imigrantes chineses recém-chegados enfrentam no Brasil.

Em 2015, Marcia Albernaz, uma fiscal do trabalho que atua em casos de escravidão chinesa no Brasil, fez declarações públicas sobre os direitos trabalhistas brasileiros. Em uma parceria entre o MPT e a Superintendência de Promoção dos Direitos Humanos do Rio de Janeiro, vários direitos foram concedidos a vítimas da escravidão sem documentos, incluindo direitos imediatos a carteira de trabalho, aulas de língua portuguesa e treinamento profissional. ${ }^{22}$ Além disso, o governo pode processar a conduta criminosa e obrigar os empregadores a pagar indenização aos trabalhadores explorados..$^{93}$ Infelizmente, muitos dos chineses sem documentos que trabalham em condições de trabalho escravo e afins podem não saber que têm direitos trabalhistas e podem temer denunciar seus empregadores por acharem que, se o fizerem, poderão ser deportados. Essas histórias contemporâneas de tráfico de trabalhadores lembram estranhamente as visões distópicas que os escritores do final do século XIX tinham sobre o futuro do Brasil, em que um híbrido Brasil-China poderia significar uma nova era de escravidão na forma de trabalho despótico chinês.

91 Eliane Lobato e Helena Borges, "Escravos chineses", Istoé, 27 nov. 2015, <http://istoe.com. br/441647_ESCRAVOS+CHINESES/>, acessado em 20/4/2017.

92 Lobato e Borges, "Escravos chineses".

93 "Chineses são resgatados de escravidão em pastelaria”, Ministério Público do Trabalho, 1 dez. 2015, <https://mpt.mp.br/pgt/noticias/chineses-sao-resgatados-de-escravidao-em-pastelaria>, acessado em 4/5/2020. 
Figura 9 - Mural de rua na Lapa, Rio de Janeiro, dezembro de 2015

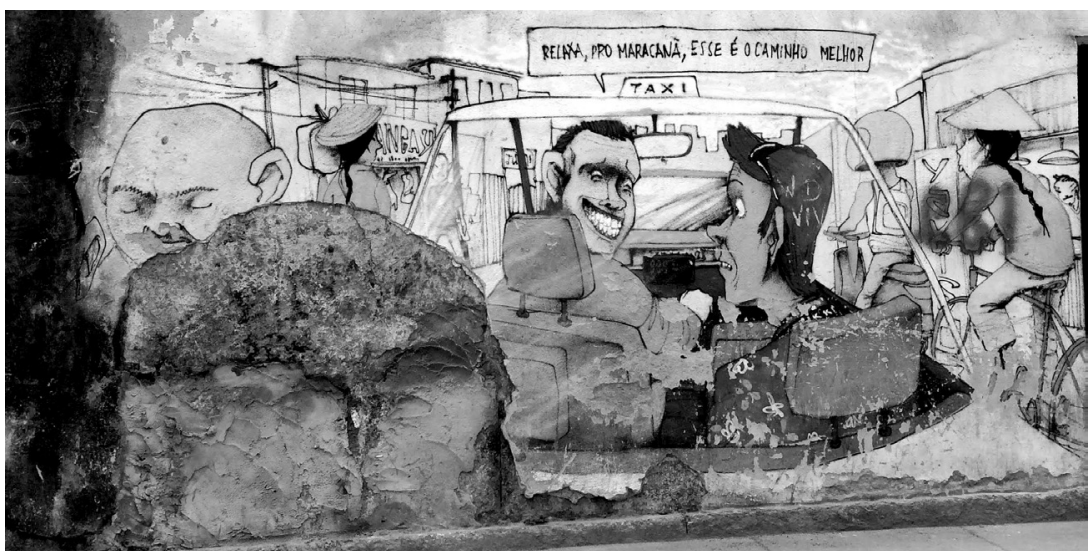

Fonte: Fotografia da autora.

A estética da exclusão do século XIX, que enquadrou os chineses como antitéticos à liberdade, ainda está presente na sociedade contemporânea, atestando a força e a persistência das memórias transatlânticas da racialização. Em uma viagem ao Rio de Janeiro em dezembro de 2015, vi um mural de rua no bairro da Lapa que mostrava um taxista levando um turista esportivo de camisa havaiana para o estádio do Maracanã (Figura 9).

$\mathrm{Na}$ rua, em ambos os lados do táxi, há caricaturas de coolies andando de bicicleta. De um lado, uma caricatura representa um ciclista chinês de gênero ambíguo, usando um chapéu de arroz em forma de cone. O perfil facial revela olhos puxados, dentes escarpados e uma longa trança, em provável referência à trança Qing. As características caricaturadas lembram com muita facilidade as representações desumanizadas e animalizadas dos chineses que circularam durante o século XIX, no auge do sentimento antichinês em todo o mundo. Os chineses fazem parte da vida cotidiana desse mural da sociedade brasileira. Eles são uma representação simbólica do trabalho precário e tão cotidiano quanto o tráfego do Rio. O estranho na cena é que o turista estrangeiro branco é retratado visualmente como sendo levado para um passeio. O taxista sorri astuciosamente. As palavras escritas na parte de cima do mural afirmam que ele levará o turista pelo melhor caminho, mas o turista o encara com 
alarme. Talvez ele tema que o taxista aplique um golpe, levando-o a um passeio mais longo e mais caro. De maneira alegórica, o mural retrata uma complexa interação estrutural de relações geopolíticas e econômicas. Brasil e China estão do mesmo lado, como atesta facilmente o bloco econômico BRICS. No entanto, desconstruindo o conhecimento cartográfico ocidental entre leste e oeste, norte e sul, e as distribuições capitalistas entre centros econômicos e periferias, o golpe no turista retrata o estrangeiro como um ser crédulo e vulnerável nas mãos da corrupção que grassaria no Brasil. O mural também sugere a visão de que o coolie não é o "outro" estrangeiro, alheio; em vez disso, o coolie é brasileiro, tão comum quanto o tráfego, e simboliza uma crítica pós-colonial pessimista do capitalismo e do regime neoliberal globais, que dependem da produção de trabalho invisível, inseguro e precário como uma condição cotidiana. Na visão sombria desse mural, a situação política e econômica contemporânea do Brasil é retrógrada e periférica.

A estética da exclusão é um arquivo crítico para examinar histórias de trabalho, formação racial e construção de nações. Reconhecer como as representações visuais da população chinesa no Brasil foram implantadas a serviço dos interesses nacionais e econômicos requer um ajuste de contas com as histórias coloniais e seus legados culturais de racialização, que continuam subjacentes à possibilidade de liberdade e aos direitos à cidadania no Brasil moderno.

Recebido em 24/11/2018 e aprovado em 04/12/2019 


\title{
Resumo
}

Este artigo examina os processos que levaram trabalhadores chineses ao Brasil, analisando documentos escritos por diplomatas e funcionários da dinastia Qing que viajaram ao Brasil para abrir rotas de imigração chinesa. As autoridades Qing utilizavam nesse contexto uma palavra que pode significar tanto imigração quanto colonização (yizhi). O Brasil, para eles, apresentava-se como uma opção viável tanto para a colonização quanto para a imigração devido ao seu vasto território e a suas leis de cidadania inclusivas. Discuto as questões levantadas por intelectuais ligados ao governo Qing sobre a abertura de rotas de imigração e comércio entre a China e o Brasil, em relação às preocupações dos abolicionistas brasileiros com a emancipação, a independência nacional e o desejo de branquear a composição racial da nova nação. Este artigo explora o que chamo de estética da exclusão para descrever a produção e a circulação de culturas visuais sobre os chineses enquanto raça, as quais contribuem para o discurso global da exclusão chinesa como uma necessidade da modernização brasileira e de seu investimento no branqueamento.

Palavras-chave: dinastia Qing - cidadania - abolição - China - teorias raciais.

\begin{abstract}
This article examines the developments that led Chinese migrant laborers to Brazil by analyzing documents written by late Qing dynasty diplomats and officials who traveled to Brazil to open up Chinese immigration routes. Qing officials used a word for immigration synonymous with colonization (yizhi). Brazil, to them, presented a viable option for both meanings due to its vast territory and inclusive citizenship laws. Late Qing officials' concerns in opening immigration and trade routes between China and Brazil regarding Brazilian abolitionists' concerns with emancipation, national independence, and the new nation's desire to whiten its racial makeup are discussed. This essay explores what I call the aesthetics of exclusion to discuss the work of Brazilian visual culture in producing and circulating ideas about the Chinese as a race, therein contributing to a global discourse of Chinese exclusion as a necessary option for Brazilian modernization and its investments in racial whitening.
\end{abstract}

Keywords: Qing dynasty - citizenship - abolition - China - racial theories. 